\title{
Evolving together: transboundary water governance in the Colorado River Basin
}

\author{
Mariana Rivera-Torres $^{1}$ (D) Andrea K. Gerlak ${ }^{2}$ (D)
}

Accepted: 8 May 2021 / Published online: 19 May 2021

(C) The Author(s), under exclusive licence to Springer Nature B.V. 2021

\begin{abstract}
Transboundary collaboration between the United States (US) and Mexico in the Colorado River Basin has heightened in recent years, as climate change, population growth, and overallocation threaten the long-term stability of the region. Through a combination of document analysis and semi-structured interviews with key stakeholders, we examine patterns of change in the governance of the Colorado River, as the US and Mexico navigate socioeconomic, cultural, and political asymmetries to jointly share water over the past two decades. We ask: What key events and environmental agreements have influenced transboundary water governance in the Colorado River over the past 20 years? We draw on the rich scholarship on transboundary water governance, especially around international river basin organizations, to uncover patterns of engagement and collaboration over time. We focus on the binational scale with an eye to study governance at multiple scales including interactions and impacts at the national and subnational scales. Our findings illustrate how Mexico's role has evolved from a narrow one following a strict interpretation of the 1944 Treaty toward a more creative partnership between the US and Mexico demonstrated in binational negotiations and the creation of joint solutions to emerging challenges around water conservation and ecological restoration. We find transboundary water governance in the basin is influenced by both long-term and short-term contextual changes that can inform strategies key actors employ to bolster institutional resilience and take advantage of opportunities for transformative change. Further, we find that the evolution of the binational relationship is reflected in changes in the negotiation process and structure, which highlights the importance of trust and relationship building, transparency, joint fact-finding, and information sharing to foster collaboration. However, we also find uneven institutionalization of stakeholder participation and transparency in engagement patterns that may ultimately, serve to hinder governance and cooperation in the basin.
\end{abstract}

Keywords Transboundary water governance $\cdot$ Stakeholder engagement $\cdot$ Binational agreements $\cdot$ River basin organizations

Mariana Rivera-Torres

mriveratorres@cbi.org

1 School of Natural Resources and the Environment, University of Arizona, Tucson, AZ, USA

2 Development and Environment and Udall Center for Studies in Public Policy, School of Geography, University of Arizona, Tucson, AZ, USA 


\section{Introduction}

Growing awareness of overallocation and drought has catalyzed collaboration in the Colorado River Basin in recent years (Bussey, 2018). In the US, the seven basin states-Arizona, California, Colorado, Nevada, New Mexico, Utah, and Wyoming-developed Drought Contingency Plans in 2019 aimed to curtail the potential for a devastating water crisis (USDOI [United States Department of Interior], 2019). Binationally, the US and Mexico jointly approved five agreements over the past decade through the International Boundary and Water Commission (IBWC), the international river basin organization (IRBO) that manages shared rivers between the two countries. These binational agreements promote shortage and surplus sharing, increased flexibility in deliveries, and ecological restoration (King et al., 2014).

Increasingly, the most significant developments in cooperative water governance are found at the river basin scale (Lindemann, 2008). The United Nations (UN) estimates that formal arrangements for water cooperation govern $63 \%$ of the world's transboundary river and lake basins and $45 \%$ of transboundary aquifers (UN-Water, 2020). In earlier research Giordano et al. (2014) reported a shifting focus from development of water resources to the management of resources and greater environmental efforts in transboundary water treaties. Over the last two decades, the number of IRBOs as venues for state interaction of international rivers has grown, in part due to support from international agencies and epistemic communities (Jaspers \& Gupta, 2014). Academics and practitioners alike ascribe to the notion that transboundary water cooperation can allow nations to benefit from implementing mutually beneficial strategies, strengthening climate resilience, and managing conflicts over water resources (De Stefano et al., 2012; United Nations Environment Programme [UNEP], 2016).

Our aim in this paper is to examine patterns of change in the governance of the Colorado River, as the US and Mexico navigate socioeconomic, cultural, and political asymmetries to jointly share water. We seek to contribute to the growing yet, divided scholarship around cooperation in the region by systematically examining the binational relationship in the Colorado River over time to more fully expose governance patterns and change. To understand how the binational relationship has evolved, we ask: What key events and environmental agreements have influenced transboundary water governance in the Colorado River over the past 20 years? We trace key events to reveal governance patterns and practices, through a combination of document analysis and qualitative interviews with key informants. We draw from the rich scholarship on transboundary water governance, especially around the role in international river basin organizations in governance, to inform our temporal analysis. We focus on the formal rule-making agency that operates at the binational scale - the IBWC - with an eye to interactions and impacts at the national and subnational scales and matters of stakeholder participation.

\section{Literature review: transboundary water cooperation and governance}

Water scholars have long studied the design and performance of institutional arrangements for transboundary water governance (e.g., Marty, 2001; Siegfried \& Bernauer, 2007), highlighting the importance of capacity to respond to changing circumstances and biophysical 
conditions (Bouckaert et al., 2018; Heikkila et al., 2013). Researchers study how IRBOs serve as regional forums to help implement transboundary water agreements, co-produce scientific knowledge, and support capacity building and joint decision-making processes (Berardo \& Gerlak, 2012; Milman \& Gerlak, 2020; Schmeier et al., 2016). Researchers have found that IRBOs can suffer from rigid institutional dependency pathways (Marshall $\&$ Alexandra, 2016) or are overly bureaucratic (Huitema et al., 2009). Others have uncovered how some IRBOs adopt an overly state-centric approach to transboundary rivers, leading to decisions that insufficiently consider localized impacts or limit the representation of stakeholders (e.g., Sneddon \& Fox, 2006; Suhardiman et al., 2012). Temporal analyses of transboundary water regimes allow researchers to track evolving dynamics and strategies within and between riparian states, which in turn shape institutional design and performance (Grey et al., 2016; Marty, 2001; Mostert, 2003).

As the joint commission that oversees and settles differences related to the application of the international boundaries and waters treaties and conventions to which the US and Mexico are parties, the IBWC has been well-studied over the years. The IBWC is composed of two national sections, the US IBWC and its Mexican counterpart, the Comisión Internacional de Límites y Aguas (CILA). Jointly, the two national sections are designed as technical and diplomatic agencies with jurisdiction over transboundary waters, including the Tijuana, Rio Grande/Bravo, and Colorado Rivers (IBWC, 1944). Researchers describe the IBWC as overly technical and narrow in its focus, secretive in its decision-making approach, and inadequate in responding to emerging challenges, protecting ecosystems, engaging stakeholders, or promoting sustainable groundwater management in the border (Ingram \& White, 1993; Ries, 2008). Political scientist Steve Mumme (2016), a long-time student of the IBWC, has described it as a highly embedded institution that is resistant to change. Despite these critiques, there is also a growing body of scholarship highlighting increased collaboration in the binational relationship over the past decade, including the emergence of a collaborative governance network around the Colorado River Delta (Delta) restoration, or the region where the river flows into the Gulf of California, that has helped shift management toward environmental values and greater participation (Bussey, 2018; De la Parra \& Heredia, 2015; Pitt \& Kendy, 2017; Sanchez \& Cortez-Lara, 2015). Emerging research suggests that the IBWC is shifting to a heightened transboundary cooperation and water diplomacy that better adapts to emerging water challenges beyond the traditional water allocation or quality concerns (King et al., 2014; Wilder et al., 2020).

Despite these debates in the scholarship, and the growing proclamations of cooperation and diplomacy in the basin, little research has systematically studied the binational relationship in the Colorado River over time to more examine governance patterns and change. In this paper, we aim to fill this gap in the scholarship by examining transboundary water governance in the Colorado River Basin over the past two decades. We analyze patterns and practices that have shaped transboundary governance by tracing key events and environmental agreements over time. In doing so, we answer the call that water scholar Kistin (2007: 8) posed more than a decade ago: to provide a "more dynamic view of transboundary water cooperation as an on-going and non-linear process in which state and non-state actors establish, challenge, modify and legitimize multi-layered governance structures."

Our analysis is theoretically guided by two important streams of scholarship in transboundary water governance-participation in water governance and multi-scalar approaches to water governance. Transboundary water governance research reflects broader international environmental policy trends, noting a shift from state-centric, topdown governance to more participatory, networked, informal governance practices (Gupta \& Pahl-Wostl, 2013; Pahl-Wostl et al., 2008). Researchers highlight the importance of 
inclusive participation in transboundary water decision-making (e.g., Gupta, 2010; Young, 2017). They draw attention to the need for greater transparency in water governance processes where all actors, including policymakers, scientists, and the public, have the potential to examine the functioning of the organization (Berardo \& Gerlak, 2012; Rogers \& Hall, 2003). In addition, researchers emphasize the need for more multi-scalar approaches to studying transboundary water governance, as shifts in water governance reflect both an upward movement toward the national or supranational and a downward trend toward the regional or local scale (Moss \& Newig, 2010). Transboundary water governance can be seen as being influenced by events and decisions "within, below, and beyond the interstate levels" (Zeitoun et al., 2017: 272), playing out at different spatial and administrative scales (Julien, 2012). As such, scholars are studying transboundary water agreements across multiple levels, from local to global (Gupta \& Pahl-Wostl, 2013; Jacobs, 2012; Mumme et al., 2012), highlighting the need to study the subnational level to better understand conflict, negotiations, and injustices (Blomquist \& Ingram, 2003; Norman \& Bakker, 2013; Zeitoun, 2013).

\section{The Colorado: an over-allocated river}

The 1400-mile Colorado River travels across seven US states, twenty-nine Tribal Nations, and two Mexican states (Baja California Norte and Sonora) toward its natural destination, the Sea of Cortez (see Fig. 1). The river is managed through a complex system of dams and diversions, providing water to approximately forty million people, irrigating over five million acres of farmland, and serving as an important source of hydroelectric power for the region (USDOI, 2019). Considered the lifeline of the Southwestern US and Northwestern Mexico, the Colorado enables the development of a vibrant economy in the desert and semi-desert through which it runs (King et al., 2014).

The binational relationship between the US and Mexico is governed by the Treaty for the Utilization of Waters of the Colorado and Tijuana Rivers and of the Rio Grande (Rio Bravo), widely known as the 1944 Water Treaty (IBWC, 1944). The treaty allotted Mexico 1.5 million acre-feet of Colorado River water annually, plus 200,000-acre feet in times of surplus or proportional reductions during "extraordinary drought" (IBWC, 1944). Allocations were estimated based on the hydrological understanding at the time and have remained fixed despite significant water supply and demand changes, climate change, and unmet environmental needs (De la Parra \& Heredia, 2015; Nava et al., 2016). As mentioned earlier, the treaty established the IBWC as the venue to resolve disputes related to its implementation and interpretation. The IBWC can develop new agreements, or Minutes, which help the treaty evolve and remain relevant to contemporary concerns (Mumme, 2020; Mumme et al., 2012; Nava \& Sandoval-Solis, 2014). Like other transboundary basins in the world, water is governed differently in the two countries: in Mexico, water is owned and managed by the federal government, whereas in the US, each basin state has ownership and agency over its allocation (Berggren, 2018; Mumme, 2016; Nava et al., 2016). As a result, transboundary water governance requires navigating asymmetrical political, institutional, and technical systems (Mumme et al., 2012; UNEP, 2016).

The US-Mexico transboundary water relationship is considered one of the most secure and reliable diplomatic arrangements between the two countries, despite the broader and complex binational relation characterized by historical grievances, uneven patterns of socioeconomic development, power asymmetries, and contentious trade and immigration 


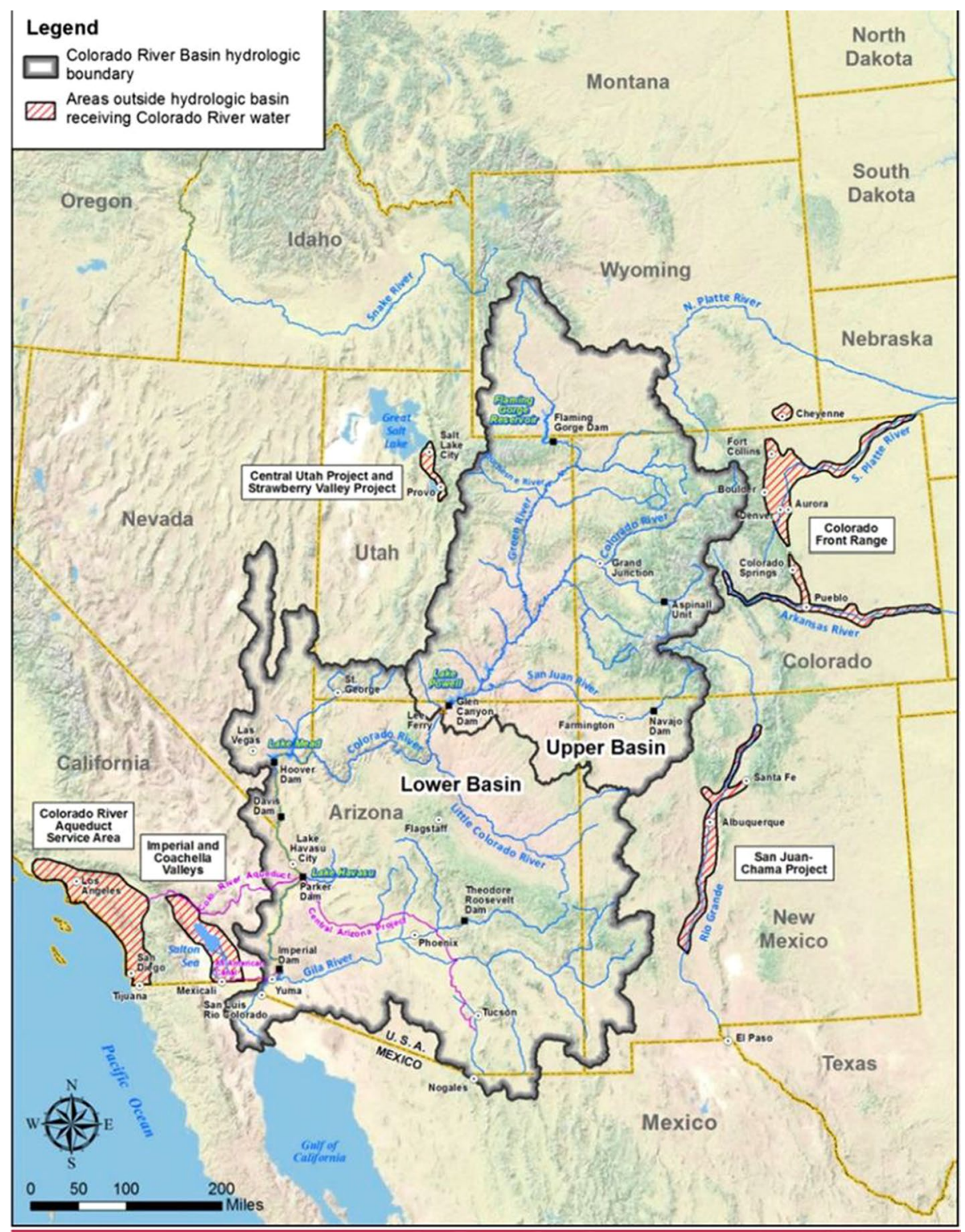

Fig. 1 The Colorado River Basin. Source: (USBR, 2015: 2)

policies (Bennett \& Herzog, 2000; Wilder et al., 2020). Experts point to the panoramic distinction and interdependence between the broader binational relationship and the regional and localized transboundary water relationship (Interview 7). Yet, this relationship is increasingly being tested in light of the growing recognition that the Colorado is over-allocated. Today, there is a "structural deficit" in the basin as more water is allocated among users than on average flows in the river itself (Mumme et al., 2018). In Mexico, Colorado River water reaches parts of Baja California Norte and Sonora but no longer reaches the 
sea (Gerlak et al., 2013). Almost two decades of sustained drought and significant risk of megadrought in the coming century indicate the impacts of future climatic changes will be greater than previously assumed (Udall \& Overpeck, 2017). Under current use patterns, the basin's largest reservoirs, Lake Mead and Lake Powell, are on track to reach critical levels which have already triggered cuts to water users (USDOI, 2019). Further, there are ongoing water disputes in the Rio Grande River (Kitroeff, 2020), another shared watershed among the US and Mexico, which could potentially have a spillover effect on binational collaboration in the Colorado River.

\section{Findings: partners in management? Recent trends in US-Mexico Colorado River relationship}

To examine the evolution of binational water agreements and transboundary relations in the Colorado River, our research follows a mixed methods approach (Creswell, 2008). We began a narrative review of academic literature and policy documents, including binational environmental agreements, diplomatic statements, joint reports, news articles and press releases. We then conducted semi-structured interviews with key players engaged in the US-Mexico cooperation process in the basin $(n=22)$ in 2019, including US and Mexican representatives from government, non-governmental, and academic institutions. We derived an initial list of interviewees through our document analysis, later expanded using the "snowball sampling" method (Naderifar et al., 2017), in which interviewees were asked to provide recommendations of other key participants in the process. Interviews were conducted in person and via the phone between April and August 2019. Interviewees represented upper and lower basin US states, federal agencies (US Bureau of Reclamation, CONAGUA, and IBWC), academic institutions (Univ. Arizona, Colegio de le Frontera, and Colorado State Univ.), and environmental NGOs (Sonoran Institute, Audubon, Pronatura Noroeste, and Western Resource Advocates). See "Appendix 1" for a list of the types of stakeholders interviewed. Due to the sensitivity of the ongoing binational diplomatic processes, participants were assured confidentiality. Interview questions focused on interviewees' role in the binational process, key events and drivers influencing transboundary governance and binational relations, and possible issues moving forward. See "Appendix 2 " for a list of interview questions.

\subsection{A bumpy road to the Colorado River Joint Cooperation Process}

Stakeholders speak of a series of events and changing hydrological conditions that led to a more robust and participatory binational cooperation process in the Colorado River Basin, as opposed to a particular singular moment in time. Modern binational cooperation in the basin can be traced to restoration efforts around the Delta. Once considered one of the most productive in the world, the Delta has been devastated by upstream development of dams and diversions (Pitt \& Kendy, 2017). Historically, the US denied legal obligations for cross-boundary environment flows, while Mexico blamed upstream management for the severe water quality and habitat deterioration (Zamora-Arroyo et al., 2007). Following a period of litigation and conflict in the 1990s, a transboundary network of environmental NGOs and researchers began drafting a new negotiation strategy (Gerlak, 2017). According to a representative active at the time, "The goal was to include the Delta environment 
in river basin decision-making, not on the sidelines, to make Mexico a part of the management of the river, not an afterthought" (Interview 9).

The first step was getting countries to acknowledge mutual responsibility. This occurred in 2000 with the US-Mexico Joint Declaration to Enhance Cooperation in the Delta, recognizing binational obligations to Article 5 of the Ramsar Convention on Wetlands (USDOI, 2000). Soon after, the IBWC approved Minute 306, establishing a binational taskforce and setting the framework for transboundary environmental collaboration (IBWC, 2000). In 2005, this taskforce developed the report Conservation Priorities in the Colorado River Delta, through which both countries began crafting a joint vision and identifying common goals and opportunities (Zamora-Arroyo et al., 2007).

Continued growth raised concerns with the overall stability of the basin. The US adopted the 2001 Interim Surplus Guidelines, which determined surplus criteria (USDOI, 2001). These negotiations involved US basin states, federal agencies, irrigation districts, and water agencies. Other stakeholders, including NGOs, tribes, and the IBWC were only allowed to contribute during the US National Environmental Policy Act (NEPA) mandated public comment period (Berggren, 2018). Despite initial consultation with Mexico, the US declared it would not assume responsibility for environmental impacts across international borders (King et al., 2014; USDOI, 2001). Lack of proper consideration of the impacts on water quality and availability in Mexico represented a major disappointment to Mexican stakeholders (Berggren, 2018; King et al., 2014). Disappointments would harden as the US moved forward with the lining of the All-American Canal (AAC), the 80-milelong canal that delivers Colorado River water to agricultural users in California's Imperial Valley, triggering perhaps the most significant binational conflict in the past two decades (Interview 9).

The AAC lining project addressed seepage, maximizing efficiency in water deliveries to the Imperial Valley but negatively impacting the farmers in Mexico's Mexicali Valley, who had become dependent on flood irrigation from canal overflow and groundwater naturally recharged by leakages (Cortez-Lara \& Garcia-Acevedo, 2000; Lesser et al., 2019). Once again, despite IBWC consultation during the NEPA public comment period, the final decision did not consider serious environmental and socioeconomic repercussions in Mexico (Cortez-Lara, 2011; Ries, 2008). As a US representative eloquently stated, "Back then, maps of the basin ended at the border; whatever happened south of it was not 'our' problem" (Interview 9).

In response to the ACC lining, businesses, civil organizations, and environmental NGOs challenged the project in US federal court, claiming it would violate Mexican users' water rights and US commitment to protect the Andrade Mesa Wetlands (Ries, 2008). The courts ruled in favor of the lining, but litigation proved to be an inappropriate approach to resolve this dispute (Cortez-Lara et al., 2009). The conflict raised old grievances, rooted in the historic salinity crisis of the 1960-1970s, and intensified Mexican farmers' distrust of US water management (Cortez-Lara et al., 2009). The US approach raised questions related to equity, interdependence of groundwater and surface water flows, and the IBWC's role in solving disputes. It accentuated underlying asymmetries in the binational relationship (Interview 7). According to Mumme (2016: 13), the AAC case is the "classic resort to sovereignty and traditional water management politics north of the border asserting water allocation claims under the drawing on the 1944 Treaty." Mexico could have taken the case to international courts, advocating for a more flexible interpretation of the 1944 Treaty and claiming the US violated the cornerstone of international law stating a country must take "all appropriate measures" not to cause significant harm to another nation's "equitable and reasonable utilization" of international waters, and resort to cooperation, including 
information sharing, consultation, and negotiation (Conca et al., 2006; Ries, 2008). Ultimately, the Mexican federal government backed down, electing not to jeopardize the broader binational relationship over the canal lining (Interview 22).

As drought persisted, the US began negotiating the basin's first shortage-sharing agreement: the Colorado River Interim Guidelines. Adopted in 2007 and in effect through 2026, the Guidelines established shortage-sharing agreements to allow for coordinated reservoir operations. Once more, the US viewed the process as a domestic matter. While the USBR models assumed Mexican contributions at different shortage triggers, Mexican stakeholders were excluded from the negotiations; participation mechanisms for appropriate binational negotiations did not exist at that time (Interview 22). Mexico was notified about the process and progress through binational meetings and learned the US wanted to establish binational shortage-sharing, purposefully avoiding activating the "extraordinary drought" clause in the 1944 Treaty (Interview 8).

Domestically, the US experienced institutional misunderstandings during the negotiations. According to a former federal government representative, the USBR did not have a "good appreciation of the role of the IBWC in the process and the implications of treaty obligations" in water management decisions at the time (Interview 17). Nor did the USBR realize the need to go through formal diplomatic procedures through the IBWC to achieve formal agreements with Mexico (Interview 17). Environmental NGOs working on both sides of the border filled this communication gap, highlighting opportunities for mutually beneficial outcomes from expanding binational cooperation, and igniting conversations between local stakeholders (King et al., 2014).

\subsection{Setting the foundation for modern binational collaboration: the CRJCP and beyond}

In this context of drought, emerging transboundary conversations, and with the desire to lessen or resolve ongoing tensions, the US and Mexican governments launched the Colorado River Joint Cooperative Process (CRJCP), through the 2007 Joint Declaration on Colorado River Issues, between the US Secretary of the Interior and the Mexican Embassy. The CRJCP formalized a binational decision to collaborate on matters related to hydrological and climate change, ecological restoration of the Delta, water conservation, augmentation, and efficiency (USDOI, 2007b). The Joint Declaration stressed that all negotiations pertaining to the basin should happen through the IBWC, recognizing Mexico as an equal partner in river governance (Berggren, 2018).

Stakeholders interviewed overwhelmingly spoke of the CRJCP as being important for trust building, consistency, continuity, knowledge co-creation, and innovative policy and management actions. The CRJCP included the establishment of the Binational Core Group, charged with binational negotiations, and four binational technical work groups, tasked with jointly analyzing and co-creating data and developing proposals with set goals, strategies, monitoring, and evaluation processes (Zamora-Arroyo et al., 2007). Membership was contingent upon a formal invitation by the IBWC and included federal and state representatives, as well as environmentalists from NGOs and universities from both countries (Bussey, 2018; King et al., 2014). In January 2009, the two countries renewed their commitment for collaboration issuing the Joint Declaration on Colorado River Issues (USDOI, 2019), setting the stage for five milestone Minutes to the 1944 Treaty.

Minute 316 represents the first binational water agreement resulting from the CRJCP. It emerged out of a long-standing conflict between environmentalists and water managers 
over the Yuma Desalination Plant (YDP) and a two-year binational consultation process seeking to mitigate the potential impacts of a pilot run to the Cienega de Santa Clara, a nearby wetland (IBWC, 2010a). Shortage-sharing conversations remained stalled until April 4, 2010, when a devastating 7.2 Richter scale earthquake hit Northern Mexico. The earthquake significantly damaged Mexican irrigation canals and inhibited Mexican officials from delivering its full Colorado River allotment (Sanchez \& Cortez-Lara, 2015). From the US perspective, this was a humanitarian issue, as well as an opportunity to be a "good neighbor" and regain trust and credibility (Interview 7). Storing Mexican water in US reservoirs provided greater flexibility and stability to the larger river system. Participants view the 2010 earthquake as "a watershed event," kicking the collaborative process into "high gear" and ultimately, shifting the dynamic of the binational relationship (Interview 16).

The crisis set into motion Minute 317, which provides a conceptual framework to guide collaboration, and Minute 318 which adjusted delivery schedules and added flexibility. Mexican researchers De la Parra and Heredia (2015: 4) refer to Minute 317 (2010) as "the official birth certificate" for what was already known as the CRJCP. It established the binational Consultative Council, composed of federal government and basin state representatives, to provide legal, administrative, and policy recommendations and explore cooperative opportunities (IBWC, 2010b). Minute 318, for the first time in history, established the conditions for temporarily storing Mexican water in US reservoirs, due to the infrastructure damage caused by the earthquake (IBWC, 2010c). On behalf of the USBR, basin stakeholders began inviting Mexicans into broader basin discussions, offering a seat at the table in the Colorado River Water Users Association, and including Mexico in the CRB Annual Operating Plan, which reports on past and projected water operations (Interview 18). Building from this cooperation, the US and Mexico signed two landmark Minutes in the coming years-Minute 319 and 323.

Experts on both sides of the border point to Minute 319 (2012) as the highlight of the CRJCP. In effect through 2017, this interim agreement brought Mexico into broader river management. Referred to by the Mexican section as "the whole enchilada" (Interview 8), Minute 319 included water conservation investments for irrigation water-use efficiency in Mexico, and unprecedented ecological restoration measures. It extended existing humanitarian stipulations and established the Intentionally Created Mexican Allocation, allowing voluntary temporary storage of Mexican water in US reservoirs (IBWC, 2012). Both countries would benefit from temporary high reservoir conditions and added flexibility, providing more adaptive water management in response to drought and climate variability (Gerlak, 2017). Remarkably, Minute 319 established a three-way commitment between the US, Mexico, and a network of NGOs to implement a pilot pulse flow in 2014, releasing up to 158,000 acre-feet of water to the riparian corridor to reconnect the river with the ocean (Berggren, 2018; Pitt \& Kendy, 2017). The pulse flow created significant momentum in favor of binational collaboration and promoted public awareness of environmental considerations in water management (Interviews 14 and 15).

The negotiations around Minute 319 faced significant obstacles (Berggren, 2018). Initially US basin states were not allowed in the room during official negotiation; as lead negotiators, federal government representatives would periodically consult with them. According to basin state representatives, the IBWC remained protective of their responsibility over shared waters, while basin states demanded participation, considering vested interests and obligations tied to binational agreements (Interview 17). Despite initial resistance from Mexico, viewing negotiations as a matter between sovereigns, in 2011 the US internally decided new agreements would require explicit consent from US state representatives (Interview 17). Soon after, the IBWC changed the structure to allow basin state 
participation, while retaining decision-making power, which as one state representative noted, led to a "sea of change," facilitating approval processes (Interview 15). The Mexican federal government decided not to include states or water users in Minute 319 negotiations, despite approximately $85 \%$ of Mexico's Colorado River allocation is used for agriculture in the Mexicali Valley in Baja California and San Luis Río Colorado in Sonora (CortezLara, 2011). At the time, it was considered "nonviable" due to lack of clear representation among agricultural users (Interview 15), as high rates of temporary water right transfers, from small-scale to large-scale farmers, had deteriorated social cohesion (Carrillo, 2009; Cortez-Lara, 2011).

Minute 323, in effect from 2017 to 2026, builds on its predecessor, provides guidelines for surplus and shortage-sharing, establishes the "Mexican Water Reserve" for additional voluntary storage, emphasizes cooperation regarding salinity and hydrological variability, includes water provisions for environmental flows for ecological restoration, and expands investment in water conservation projects in Mexico (IBWC, 2017). Minute 323 establishes the Binational Water Scarcity Contingency Plan (BWSCP), through which both countries will reduce additional volumes of water based on Lake Mead elevations. The BWSCP was negotiated parallel to the Drought Contingency Plans in the Lower Basin and was contingent upon their approval (IBWC, 2017). Mexico made a concession by being treated as an equal in terms of US consumptive uses and taking a greater proportional cut under lowest reservoir levels than the Lower Colorado Basin states altogether (IBWC, 2017). While some claim Minute 323 furthers the concept of equitable apportionment by affirming the proportional sharing of drought and reciprocal right to surplus (Bussey, 2018), others criticize it for setting a dangerous precedent by allowing the US to exchange money for water to fulfill 1944 Treaty obligations (Lewis, 2019).

Although representatives from Mexican states and irrigation districts were invited into the binational process, Minute 323 was signed in secret before the public signing ceremony due to lack of popularity among some farm and labor unions in Mexico (Interview 9). As a result, researchers have raised questions of fairness, transparency, and equity for the Mexicali farmers (Interviews 6, 7, and 11) and the Cocopah (also Cucapá) Tribe, who live along the lower Colorado River and Delta, and according to some observers have not been sufficiently engaged in recent negotiations (Lewis, 2019).

\section{Conflict and cooperation in Colorado River governance: changing perceptions and patterns of engagement}

We observe an ebb and flow of conflict and cooperation in the region over the past two decades. Modern cooperation strengthened through the emergence of a collaborative governance network, led by an environmental NGO coalition bound together through mutual concern over the Delta. Minute 306 generated optimism for binational collaboration, but this positivity was quickly clouded by a series of disagreements over the ACC Lining dispute and the adoption of the 2001 and 2007 Interim Guidelines that degraded trust between the US and Mexico. These conflicts were connected to increased pressure on water resources and highlighted the inadequacy of binational consultation provisions at the time (King et al., 2014).

Consistent with Mirumachi and Allan (2007), increased water scarcity and population growth in the basin, along with environmental degradation in the Delta, heightened conflict intensity in the region. Although seemingly opposing, increased conflict intensity paired 
with increased collaboration around ecological restoration, led both countries to establish the CRJCP and shaped the content and process behind a series of groundbreaking transboundary agreements. Tensions served as catalysts for transboundary collaboration (Zeitoun \& Mirumachi, 2008), as we can see through more than a decade of active participation in the CRJCP.

The CRJCP illustrates how effective cooperation goes beyond signing a treaty and establishing an IRBO, but rather depends on the interplay of a number of factors over time, including continued commitment to cooperation, strong and well-funded transboundary institutions, key actors' leadership and ability to take advantage of emerging opportunities and adapt to changing conditions (Marty, 2001; Renner et al., 2020). The co-production of science by transboundary work groups and the increased involvement of binational NGOs are key drivers of cooperation and an expanding stakeholder process (Gerlak, 2017). This aligns with a growing body of scholarship around the importance of collaboration in the production of science to support more effective and participatory water governance (e.g., Armitage et al., 2015; Bouleau, 2014; Edelenbos et al., 2011; Milman \& Gerlak, 2020).

Through our temporal analysis covering the past two decades (2000-2019), we observe how transboundary water agreements are influenced by long-term environmental, institutional, socioeconomic, and political changes, as well as by short shock periods like natural disasters, that can provide opportunities for transformative change (Renner et al., 2020). Figure 2 illustrates key events and agreements in the binational relationship over the past two decades. This includes a diverse set of events that shape and transform the binational relational across multiple scales from the subbasin to the national and international, reflecting the multi-level governance that characterizes water governance (Gupta \& PahlWostl, 2013). It includes events that can be seen as more long-term in nature, reflecting legal negotiation processes, like the Minutes to the 1944 Treaty, and also more short-term shocks, like the 2010 earthquake. Consistent with Renner et al. (2020), we observed how long-term and short-term contextual changes can inform strategies key actors employ to bolster the resilience of transboundary institutions and take advantage of these opportunities to pass unprecedented transboundary water management strategies like the shortagesharing guidelines. We find shock events can accelerate change and provide opportunities for actions and policies not previously possible in situations where the groundwork has been laid through trust building and information sharing.

Most experts in the basin point to the CRJCP as a key milestone, serving to shift Mexico's role in river management from a passive recipient of water, following a strict interpretation of the 1944 Water Treaty, to an active participant in decision-making (Interview 22). Throughout our interviews, Mexico's current role in basin governance was described by diverse stakeholders on both sides of the border, as "growing," "emerging," "solid,"

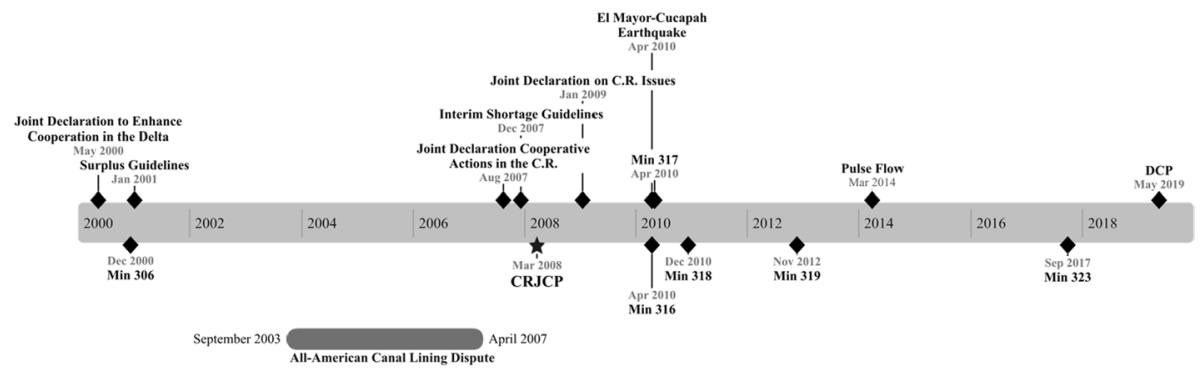

Fig. 2 Key events and agreements in US-Mexico Colorado River relationship in the twenty-first century 
"technical," and "internalized," transcending administration changes on both countries (Interviews 1, 2, 3, 4, 6, 7, 10, 12, 13, 15, and 16). This is in contrast to earlier views of the binational relationship where Mexico was perceived to serve in more of a "subservient" role (Interview 17). One Mexican researcher characterizes it this way: "It was like Mexico was a sort of passenger; the US would decide where to go and the passenger was expected to go there. Although they (US) were looking for Mexico's good will, there was no understanding or awareness of how to negotiate" (Interview 5).

In addition, insiders to the negotiations emphasized the significance of establishing a shared technical language and of time spent understanding each other's positions and negotiation styles, exploring possible actions and their political and economic implications on both countries (Interview 10). Initially, each country had separate data and hydrological models, which created significant inconsistencies and generated skepticism (Interview 17). After four years exploring alternatives, the group determined the Colorado River Simulation System used by the USBR was robust enough to be useful for both countries. The USBR shared the technology, expertise, and rationale behind management decisions with Mexican stakeholders through a series of technical trainings (Interview 10). As a US basin state representative stated, having "the same data, same tools, and similar technical conclusions" significantly accelerated the conversation, illustrating the need for transparency and information sharing to build trust in the negotiations of transboundary agreements (Interview 10). The CRJCP also included a series of binational trips to familiarize stakeholders on water management realities and limitations in their respective countries (Mumme et al., 2018). Binational trips and compatible hydrological modeling played important roles in promoting transparency, which is thought to bolster effectiveness, legitimacy, effective governance, and sustainability in the transboundary context (Berggren, 2018; Gupta, 2010).

Through the CRJCP, Mexican stakeholders demonstrated their ability to diplomatically achieve mutually beneficial agreements in times of scarcity. Figure 3 illustrates how Mexican participation, and thus the scope of binational agreements, was limited prior to the CRJCP around water deliveries and salinity issues. Following the CRJCP, or post-CRJCP, Mexico is more engaged on a number of fronts from water deliveries to ecological restoration. Mexico conceded to shortage-sharing, but it also shares in surplus, has greater flexibility in deliveries, and receives US funding for investments in water conservation projects and ecological restoration. In the transboundary context,

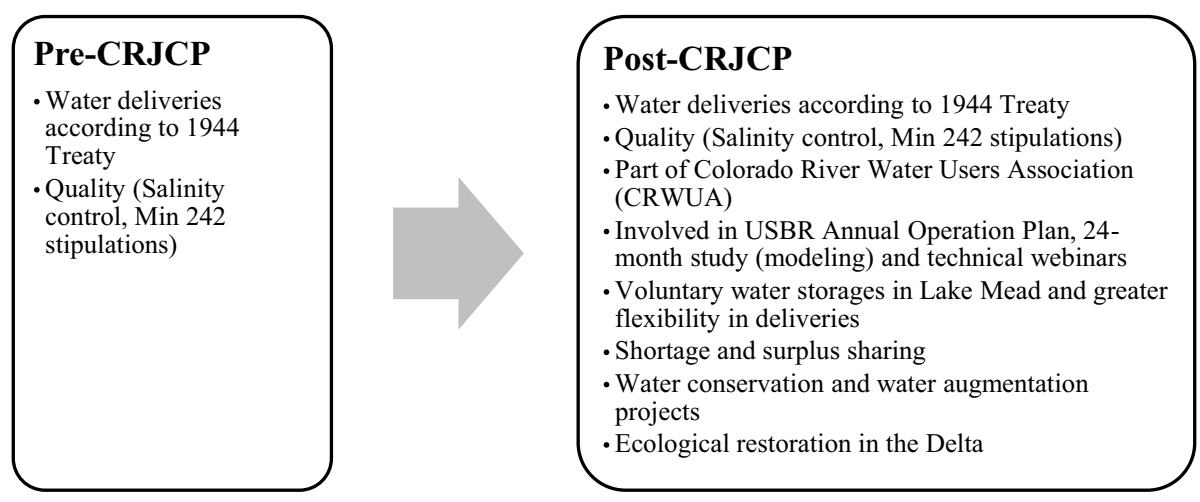

Fig. 3 Scope of Mexican participation in Colorado River Basin 
Hamilton (2018) argues that the ultimate effectiveness of collaboration depends on whether participants perceive processes to be fair, which in turn depends on participants' opportunities to influence policy outcomes and goes beyond consultation at initial stages or merely having a seat at the table.

The evolution of the binational relationship is also reflected in changes in the negotiation process and structure. Historically, the two countries interacted only through formal, diplomatic processes. Although the CRJCP remains under the IBWC umbrella, it has evolved to encompass a combination of formal negotiations among the high-level policy group (Minute Negotiating Group, which turns into the Minute Oversight Group) and various binational technical work groups (i.e., environmental, projects, salinity, hydrology, desalination, AAC, etc.) (Interviews 14, 15, 18, 19, and 20). Figure 4 illustrates the structure of the collaborative process and patterns of stakeholder engagement that have resulted under the CRJCP. The arrows portray how federal, state, water users, academic, and environmental representatives on both sides of the border actively participate and represent their interests in the collaborative process. Binational work groups develop the groundwork for complex negotiations and co-produce scientific knowledge to guide decision-making (i.e., Minute 319 Colorado River Limitrophe and the Delta Environmental Flows Monitoring Initial Progress Reports). Throughout the process, stakeholders continually interact to identify issues, analyze technical approaches, and craft joint strategies. The high-level policy group oversees the work groups and assesses policy implications. At the center, IBWC Commissioners support the work groups, analyze the information and recommendations received, and importantly, retain decisionmaking power over binational agreements.

Although the binational environmental coalition plays an important role as advocate for environmental interests, facilitator, and program implementer, working group participation is not permanent (Lewis, 2019). Further, the Binational Environmental Work Group serves a purely advisory role unable to make binding recommendations to the IBWC. There is a lack of transparency in these new processes, especially in terms of a shortage of publicly available data on membership and meeting summaries associated with the work groups. This limits the potential of transparency to inform and empower, and help achieve more accountable, legitimate, and democratic governance (Gupta,

Fig. 4 CRJCP stakeholder engagement process. Source: Adapted from (Cullom, 2018)

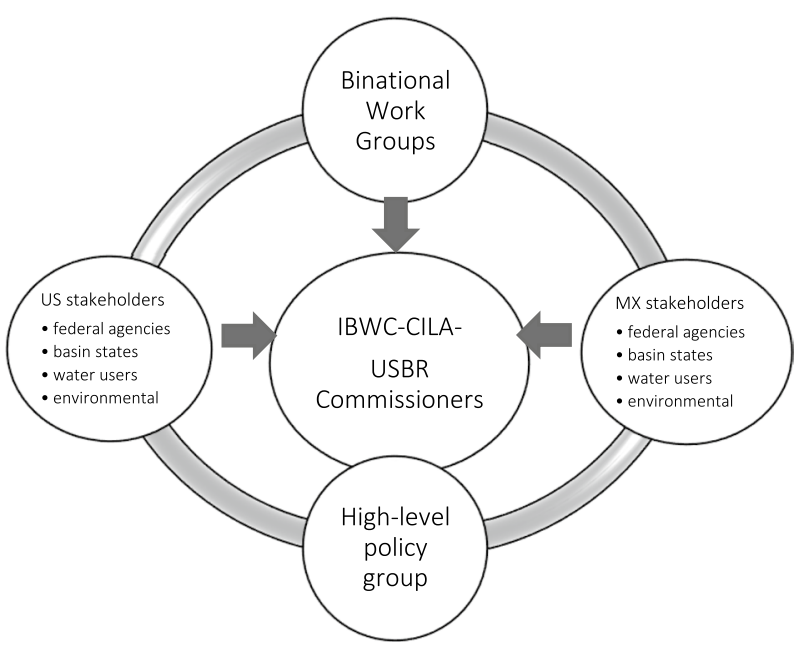


2010). As water scholar Helen Ingram (2006: 429) argues, "only institutions that are inclusive, open, transparent, and accountable can bring legitimacy to decisions affecting the many conflicting water values with a realistic expectation of implementation."

Despite changing views and new patterns of engagement, concern remains that not all stakeholders at the subnational level have been equally engaged in the development of transboundary water agreements. Some researchers have noted that the Cocopah (also Cucapá) Tribe has not been sufficiently engaged in recent negotiations nor in the network of actors working on the restoration in the Delta (Lewis, 2019). The 1944 Treaty includes only the two neighboring nations as parties with standing, and as such, US and Mexico are not required to consult with affected sovereign tribal nations (Lewis, 2019). In addition, despite significant investments in irrigation efficiency projects in the Mexicali Valley, some farmer unions, particularly the Citizen Committee in Defense of Baja California's Water, remain skeptical about the process, claiming the IBWC is "selling their water" to the US (García, 2018). This concern stems from grievances dating back to the salinity crisis of the 1960-1970s and the more recent AAC lining dispute (Interview 7). Further, farmers in Mexico face consistent challenges related to water quality and availability, due to high salinity concentrations in US deliveries, displacement of small-scale farming (Carrillo, 2009), shifting urban and rural dynamics (Cortez-Lara, 2011), increased reliance on overexploited groundwater systems, and emerging disputes connected to the construction of a large brewery, threatening local water supplies (Agren, 2018).

Several Mexican representatives acknowledge the need for stronger public engagement, as earlier attempts by the IBWC to establish public meetings in Mexico were discontinued (Interviews 11, 10, and 22). Some suggest that Mexican federal entities "block or limit participation in order to make things go fast and effectively; so, decisions made on behalf of farmers are perceived as an imposition" (Interview 11). Although some Mexican authorities suggest these claims do not to represent the majority of users, a representative acknowledged the need for improved communication, transparency, and engagement with agricultural users, who will be impacted by stipulations approved in recent negotiations (Interviews 19 and 22). Similarly, NGO representatives highlight the importance of establishing a comprehensive communication strategy to share the rationale behind recent agreements, communicate the impact of drought and climate change on existing water resources, strengthen community resilience, foster trust, and encourage local support for sustained binational collaboration (Interviews 3, 4, 6, and 9). This speaks to the rich scholarship around stakeholder engagement in transboundary water governance that highlights the importance of trust, defined processes, and equal relations to support meaningful engagement (e.g., Berardo \& Gerlak, 2012; Jacobs, 2012; Schulz, 2012; Wehn, et al., 2018).

\section{Conclusions}

In this paper, we examine patterns in transboundary collaboration in the Colorado River Basin over the past two decades, tracing key events and binational environmental agreements over time. This research provides an interesting case study that broadens our understanding of transboundary water governance for two important reasons. First, our study contributes to the ongoing debates in the scholarship around the nature of the binational relationship between the US and Mexico over the Colorado River, and the role of the IBWC in the transboundary governance. We offer a temporal analysis, looking at change over the past two decades, drawing on perspectives from key players "inside" and "outside" 
the decision-making table (Renner et al., 2020). As such, this research contributes to the scholarship through its focus on transboundary water governance as evolving and dynamic, with an institutional landscape shaped by patterns of conflict and cooperation among stakeholders at multiple levels. Second, from a policy perspective, this research is timely given the upcoming renegotiations of domestic and binational drought contingency plans and shortage-sharing guidelines in the basin, which will significantly impact water governance in the region for years to come.

Taken together, we observe an ebb and flow of conflict and cooperation, along with changing perceptions and patterns of stakeholder engagement. Our findings speak to Mexico's evolving role, from a narrow, limited role following strict interpretation of the 1944 Treaty toward a more creative partnership demonstrated in recent binational agreements, namely Minutes 316, 317, 318, 319, and 323. This suggests evidence of a heightened collaboration characterizing the binational relationship between the US and Mexico on shared Colorado River governance. We observe how water governance is influenced by long-term and short-term contextual changes that can inform strategies key actors employ to bolster the resilience of transboundary institutions and take advantage of opportunities for transformative change. Our study illustrates the evolution of the binational relationship is also reflected in changes in the negotiation process and structure, which highlights the importance of trust and relationship building, transparency, knowledge co-production, and information sharing to foster collaboration.

Yet, this research also uncovers an uneven institutionalization of participation and transparency in the basin. There exist concerns that some stakeholders at the subnational level-especially tribes in the lower Colorado region and farmers in the Mexicali Valley-have been insufficiently engaged. Further, there is a lack of transparency associated with some of the new collaborative processes around restoration of the Delta. Among other benefits, ensuring adequate and diverse participation could help gain political support and credibility, disprove misinformation, diminish sources of conflict and unnecessary costs, validate users' concerns, and create awareness of the threats posed by climate change and the benefits of cooperation across borders (Ingram, 2006).

This research contributes to the scholarship through its temporal and multi-scalar analysis, focused on transboundary water governance as evolving and dynamic, with an institutional landscape shaped by patterns of conflict and cooperation among stakeholders at multiple levels. From a policy perspective, this research comes at a critical period in the Colorado River given the upcoming renegotiations of domestic and binational drought and water scarcity contingency plans, which will have significant impacts on water governance in the region. Yet, we would be remiss if we did not acknowledge the limitations and limited generalizability of our research. Future research might more fully examine power asymmetries and dynamics inside the binational work groups. Field research could shed greater light on the interests and claims of the tribes and Mexican farmers in negotiations and governance. Further, this research did not fully capture the impact of the latest political changes in transboundary water governance processes. At a December 2020 workshop one of our authors participated in, Mexican researchers expressed concern that new administrative changes and turnovers in Mexico have led to a lack of coherent water policy and strategy, impacting the US-MX binational relationship and widening the disconnect between the federal narrative and local water concerns.

With the domestic and binational shortage guidelines and drought contingency plans set to expire in 2026, the coming years will test the strength of the current binational cooperation process and offer opportunities to experiment with new engagement strategies. Can regional cooperation remain strong, despite changing administrations, ongoing 
militarization of the US-Mexico border and expansion of a border wall dissecting and threatening the shared environmental landscape (Maine, 2020), growing animosity in the Rio Grande/Bravo watershed (Kitroeff, 2020), climate pressures, and the new limitations and engagement challenges presented by the COVID-19 pandemic? Recognizing that collaboration can be difficult, slow-moving, and time consuming, all eyes are focused to see how Mexico is engaged, or not, in the forthcoming negotiation process and whether that engagement is done in a respectful, fair, and mutually beneficial manner to all stakeholders in the Colorado River basin.

\section{Appendix 1: Interviewee list}

\begin{tabular}{lll}
\hline Number & Interest/Category & Country \\
\hline 1 & Former Basin-state representative & US \\
2 & Environmental NGO representative & US \\
3 & Environmental NGO representative & Mexico \\
4 & Environmental NGO representative & US \\
5 & Research/Academia representative & Mexico \\
6 & Environmental NGO representative & Mexico \\
7 & Research/Academia representative & US \\
8 & Former federal agency representative & Mexico \\
9 & Environmental NGO representative & US \\
10 & Basin-state representative & US \\
11 & Research/Academia representative & Mexico \\
12 & Federal agency representative & US \\
13 & Basin-state representative & US \\
14 & Basin-state representative & US \\
15 & Basin-state representative & US \\
16 & Research/Academia representative & US \\
17 & Former federal agency representative & US \\
18 & Federal agency representative & US \\
19 & Federal agency representative & Mexico \\
20 & Federal agency representative & Mexico \\
21 & Former federal agency representative & US \\
22 & Federal agency representative & Mexico \\
\hline & &
\end{tabular}

\section{Appendix 2: Sample interview questions}

\section{Background and role in the process}

- Can you tell me a little bit more about your work and experience related to the Colorado River and US-Mexico relations?

- How would you describe your role and your institution's role in the binational process? 
- If applicable, could you tell me more about the binational working group you are part of?

\section{Mexico \& water governance}

- How would you describe Mexico's role in Colorado River governance?

- When we say Mexico, what do we mean? What stakeholders come to mind?

- Has this role changed in the past decades? In what ways?

- What drivers do you think influenced these changes? Leadership, non-governmental organizations, emergencies?

- What are your perceptions on the different stakeholders' (US, Mexico, states', water utilities' and NGO sectors') participation in the negotiation and implementation of recent IBWC Minutes (317, 318, 319 and 323)?

- How do other stakeholders engage in the basin? What does that look like? Seen as an equal?

\section{Binational relationship}

- How has the relationship (US-Mex) changed over time? Why? (Leadership, need, binational NGOs?) What has worked? What has not?

- Is there any key moment/event that changed or influenced this relationship?

- Based on the timeline: Are there any key moments I am missing? Are there any that you don't deem as important?

- Have evolved in any way from conflict and litigation toward collaboration and cooperation? Do you think any further evolution in the discussions would be beneficial?

- Are there other venues, besides the IBWC for binational collaboration in the basin?

- Is the conversation structured in a way to ensure an inclusive approach? Are there processes that you have seen or are familiar with that do engagement better?

\section{Shortage-sharing guidelines}

- Did Mexico play any role in the negotiation of the 2007 Shortage Guidelines (Colorado River Interim Guidelines for Lower Basin Shortages and the Coordinated Operations for Lake Powell and Lake Mead)? Was Mexico included in the conversation? Why or why not?

- What do you foresee Mexico's role to be in the process of renegotiations? 2020-2026

- What are possible pathways for Mexico's engagement in the renegotiation of the guidelines?

- What do you see as the key issues moving forward? Do you think the conversation will/should evolve from referring to drought (short-term) toward incorporating climate change (long-term)?

\section{Other contacts/recommendations}

- Are there other key individuals engaged in the process that we should be contact? Do you have any recommendations for our research (resources, etc.)? 
Acknowledgements We are grateful to our exceptional Colorado River Conversations Project team, Kathy Jacobs, Amanda Leinberger, Amy McCoy, Season Martin, and Anna Murveit. We would also like to thank the Walton Family Foundation for funding this research, and all the experts on both sides of the border, who took the time to share their experiences and insight. Without your participation and input, the study could not have been successfully conducted.

Author contributions All authors contributed to the study conception and design, material preparation, and analysis. Interviews were performed by MR-T. All authors wrote the first draft, commented on previous versions of the manuscript, and approved the final manuscript.

Funding The project team is grateful to the Walton Family Foundation for their support of the larger Colorado River Conversations Project and for funding this research.

\section{Declarations}

Conflict of interest The authors have no conflicts of interest to declare that are relevant to the content of this article.

Ethical approval (Include appropriate approvals or waivers) All procedures performed in studies involving human participants were in accordance with the ethical standards of the institutional and/or national research committee and with the 1964 Helsinki declaration and its later amendments or comparable ethical standards. The University of Arizona's Institutional Review Board (IRB), an independent review committee charged with the protection of human research subjects, reviewed all research and related activities involving human subjects conducted the authors.

Consent to participate Informed consent was obtained from all individual participants included in the study.

Consent for publication All authors read and approved the final manuscript.

\section{References}

Agren, D. (2018). Mexico protesters fear US-owned brewery will drain their land dry. The Guardian.

Armitage, D., de Loë, R. C., Morris, M., Edwards, T. W. D., Gerlak, A. K., Hall, R. I., \& Wolfe, B. B. (2015). Science-policy processes for transboundary water governance. Ambio, 44(5), 353-366.

Bennett, V., \& Herzog, L. A. (2000). US-Mexico borderland water conflicts and institutional change: A commentary. Natural Resources Journal, 973-988.

Berardo, R., \& Gerlak, A. K. (2012). Conflict and cooperation along international rivers: Crafting a model of institutional effectiveness. Global Environmental Politics, 12(1), 101-120.

Berggren, J. (2018). Utilizing sustainability criteria to evaluate river basin decision-making: The case of the Colorado River Basin. Regional Environmental Change, 18(6), 1621-1632.

Blomquist, W., \& Ingram, H. M. (2003). Boundaries seen and unseen. Water International, 28(2), 162-169.

Bouleau, G. (2014). The co-production of science and waterscapes: The case of the Seine and the Rhône Rivers, France. Geoforum, 57, 248-257.

Bouckaert, F., Wei, Y., Hussey, K., Pittock, J., \& Ison, R. (2018). Improving the role of river basin organisations in sustainable river Basin governance by linking social institutional capacity and basin biophysical capacity. Current Opinion in Environmental Sustainability, 33, 70-79.

Bussey, O. W. (2018). In good times and in bad: An international water law analysis of minute 323. Georgetown International Environmental Law Review, 31, 157-182.

Carrillo-Guerrero, Yamilett K. (2009). Water conservation wetland restoration and agriculture in the Colorado River Delta Mexico. Unpublished manuscript University of Arizona.

Conca, K., Wu, F., \& Meri, C. (2006). Global regime formation or complex institution building? The principled content of international river agreements. International Studies Quarterly, 50(2), 263-285.

Cortez-Lara, A., \& Garcia-Acevedo, M. R. (2000). The lining of the All-American canal: The forgotten voices. Natural Resources Journal, 40, 261-280.

Cortez-Lara, A., Donovan, M. K., \& Whiteford, S. (2009). The All-American canal lining dispute: An American resolution over Mexican groundwater rights? Frontera Norte, 21, 41. 
Cortez-Lara, A. (2011). Gestión y manejo del agua: el papel de los usuarios agrícolas del Valle de Mexicali. Problemas del Desarrollo Revista Latinoamericana de Economía, 42, 71-95.

Creswell, J. W. (2008). Research design: Qualitative, quantitative, and mixed methods approaches. Sage Publications.

Cullom, C. (2018). Minute 323 Binational Study of desalination opportunities in the sea of Cortez region. Central Arizona Project Board.

De la Parra, C. A., \& Heredia, C. (2015). Lessons from the development of binational and civil society cooperation on water management at the U.S.-Mexico border. DC: Wilson Center Mexico Institute.

De Stefano, L., Duncan, J., Dinar, S., Stahl, K., Strzepek, K. M., \& Wolf, A. T. (2012). Climate change and the institutional resilience of international river basins. Journal of Peace Research, 49(1), 193-209.

Edelenbos, A., Van Buuren, A., \& Van Schie, N. (2011). Co-producing knowledge: Joint knowledge production between experts, bureaucrats and stakeholders in dutch water management projects. Environmental Science \& Policy, 14(6), 675-684.

García, A. (2018). El agua: La polémica que enfrenta a México y estados unidos. El Universal.

Gerlak, A. K. (2017). Regional water institutions and participation in water governance: The Colorado River Delta as an exception to the rule? Journal of the Southwest, 59(1-2), 184-203.

Gerlak, A. K., Zamora-Arroyo, F., \& Kahler, H. P. (2013). A Delta in repair: Restoration, binational Cooperation, and the future of the Colorado River Delta. Environment: Science and Policy for Sustainable Development, 55(3), 29-40.

Giordano, M., Drieschova, A., Duncan, J. A., Sayama, Y., De Stefano, L., \& Wolf, A. T. (2014). A review of the evolution and state of transboundary freshwater treaties. International Environmental Agreements: Politics, Law and Economics, 14(3), 245-264.

Grey, D., Sadoff, C., \& Connors, G. (2016). Effective cooperation on transboundary waters: A practical perspective. World Bank.

Gupta, A. (2010). Transparency in global environmental governance: A coming of age? Global Environmental Politics, 10(3), 1-9.

Gupta, J., \& Pahl-Wostl, C. (2013). Global water governance in the context of global and multilevel governance: Its need, form, and challenges. Ecology and Society. https://doi.org/10.5751/ES-05952-180453

Hamilton, M. (2018). Understanding what shapes varying perceptions of the procedural fairness of transboundary environmental decision-making processes. Ecology and Society, 23(4), 48.

Heikkila, T., Gerlak, A. K., Bell, A., \& Schmeier, S. (2013). Adaptation in a transboundary river basin: Linking stressors and adaptive capacity within the Mekong River commission. Environmental Science and Policy, 25, 73-82.

Huitema, D., Mostert, E., Egas, W., Moellenkamp, S., Pahl-Wostl, C., \& Yalcin, R. (2009). Adaptive water governance: assessing the institutional prescriptions of adaptive (co-) management from a governance perspective and defining a research agenda. Ecol Soc 2009, 14 http://www.ecologyandsociety.org/ vol14/iss 1/art26/.

Ingram, H., \& White, D. R. (1993). International boundary and water commission: An institutional mismatch for resolving transboundary water problems. Natural Resources Journal, 33, 153.

Ingram, H. (2006). Water as a multi-dimensional value: Implications for participation and transparency. International Environmental Agreements: Politics, Law and Economics, 6, 429-433.

International Boundary and Water Commission. (1944). Treaty relating to utilization of waters of the Colorado and Tijuana Rivers and of the Rio Grande, US-Mexico. 59 State 1219, February.

International Boundary and Water Commission. (2000). Conceptual framework for US-MX studies for future recommendations concerning the riparian and estuarine ecology of the limitrophe section of the Colorado River and its associated delta, Minute No 306. June 17.

International Boundary and Water Commission. (2010a). Conceptual framework for US Mexico discussions on Colorado River cooperative actions, Minute No 316, April 16.

International Boundary and Water Commission. (2010b). Conceptual framework for US Mexico discussions on Colorado River cooperative actions, Minute No 317, June 25.

International Boundary and Water Commission. (2010c). Cooperative measures to address the continued effects of the April 2010 earthquake in the Mexicali Valley, Baja California, Minute No 318, December 17 .

International Boundary and Water Commission. (2012). Interim international cooperative measures in the Colorado River Basin through 2017 and extension of minute 318 cooperative measures to address the continued effects of the April 2010 earthquake in the Mexicali Valley, Baja California, Minute No. 319, November 20.

International Boundary and Water Commission. (2017). Extension of cooperative measures and adoption of a binational water scarcity contingency plan in the Colorado River Basin, Minute No 323, September 21. 
Jacobs, I. M. (2012). A community in the orange: The development of a multi-level water governance framework in the Orange-Senqu River basin in Southern Africa. International Environmental Agreements, 12, 187-210.

Jaspers, F., \& Gupta, J. (2014). Global water governance and river basin organisations. In D. Huitema \& S. Meijerink (Eds.), The politics of River Basin organisations: Coalitions, institutional design choices and consequences (pp. 38-66). Edward Elgar Publishing.

Julien, F. (2012). Hydropolitics is what societies make of it (or why we need a constructivist approach to the geopolitics of water). International Journal of Sustainable Society, 4(1-2), 45-71.

King, J. S., Culp, P. W., \& De la Parra, C. A. (2014). Getting to the right side of the river: Lessons for binational cooperation on the road to Minute 319. University of Denver Water Law Review, 36(52-53), 81.

Kitroeff, N. (2020). 'This is a war': Cross-border fight over water erupts in Mexico. New York Times.

Kistin, E. K. (2007). Trans-boundary cooperation in SADC: from concept to implementation. In 8th WaterNet/WARFSA/GWP-SA Symposium, Lusaka, Zambia (Vol. 30).

Lesser, L. E., Mahlknecht, J., \& López-Pérez, M. (2019). Long-term hydrodynamic effects of the All-American canal lining in an arid transboundary multilayer aquifer: Mexicali valley in North-Western Mexico. Environmental Earth Sciences, 78(16), 504.

Lewis, M. J. (2019). Minute by minute: An assessment of environmental flows program for restoration of the Colorado River Delta. Wyoming Law Review, 19, 231-257.

Lindemann, S. (2008). Understanding water regime formation: A research framework with lessons from Europe. Global Environmental Politics, 8(4), 117-140.

Main, D. (2020). The U.S. border wall is tearing through wilderness, right under our noses. National Geographic.

Marshall, G. R., \& Alexandra, J. (2016). Institutional path dependence and environmental water recovery in Australia’s Murray-Darling Basin. Water Alternatives, 9, 679-703.

Marty, F. (2001). Managing international rivers: Problems, politics, and institutions. Peter Lang.

Milman, A., \& Gerlak, A. K. (2020). International river basin organizations, science, and hydrodiplomacy. Environmental Science \& Policy, 107, 137-149.

Mirumachi, N., \& Allan, J. A. (2007). Revisiting transboundary water governance: Power, conflict cooperation and the political economy. In Mirumachi, Naho, and John Anthony Allan. In Proceedings from CAIWA international conference on adaptive and integrated water management: Coping with scarcity. Vol. 1215.

Moss, T., \& Newig, J. (2010). Multilevel water governance and problems of scale: Setting the stage for a broader debate. Environmental Management, 46(1), 1-6.

Mostert, E. (2003). Conflict and co-operation in international freshwater management: A global review. International Journal of River Basin Management, 1(3), 267-278.

Mumme, S. P., Ibáñez, O., \& Till, S. M. (2012). Multilevel governance of water on the US-Mexico border. Regions and Cohesion, 2(2), 6-29.

Mumme, S. P. (2016). Scarcity and power in US-Mexico transboundary water governance: Has the architecture changed since NAFTA? Globalizations, 13(6), 702-718.

Mumme, S. P., Ibanez Hernandez, O., \& Verdini, B. (2018). Extraordinary drought in US-Mexico water governance. Water Law, 26, 1-16.

Mumme, S. P. (2020). The 1944 water treaty and the incorporation of environmental values in US-Mexico transboundary water governance. Environmental Science \& Policy, 112, 126-133.

Naderifar, M., Goli, H., \& Ghaljaie, F. (2017). Snowball sampling: A purposeful method of sampling in qualitative research. Strides in Development of Medical Education, 14(3), 1-6.

Nava, L. G., Brown, C., Demeter, K., Lasserre, F., Milanes-Murcia, M., Mumme, S., \& Sandoval-Solis, S. (2016). Existing opportunities to adapt the Rio Grande/Bravo basin water resources allocation framework. Water, 8(7), 291.

Nava, L. F., \& Sandoval-Solis, S. (2014). Multi-tiered Governance of the Rio Grande/Bravo Basin: The fragmented water resources management model of the United States and Mexico. International Journal of Water Governance, 2(1), 85-106.

Norman, E. S., \& Bakker, K. (2013). Rise of the local? Delegation and devolution in transboundary water governance. In E. S. Norman, A. Cohen, \& K. Bakker (Eds.), Water without borders?: Canada, the United States, and shared waters (pp. 47-69). University of Toronto Press.

Pahl-Wostl, C., Gupta, J., \& Petry, D. (2008). Governance and the global water system: A theoretical exploration. Global Governance: A Review of Multilateralism and International Organizations, 14(4), 419-435.

Pitt, J., \& Kendy, E. (2017). Shaping the 2014 Colorado River Delta pulse flow: Rapid environmental flow design for ecological outcomes and scientific learning. Ecological Engineering, 106, 704-714. 
Renner, T., Meijerink, S., van der Zaag, P., \& Smits, T. (2020). Assessment framework of actor strategies in international river basin management, the case of Deltarhine. International Environmental Agreements: Politics, Law and Economics, 1-29.

Ries, N. (2008). (Almost) All-American canal: Consejo de desarrollo economico de Mexicali v. United States and the pursuit of environmental justice in transboundary resource management. Ecology $L Q$, $35,491$.

Rogers, P., \& Hall, A. W. (2003). Effective water governance. Global Water Partnership.

Sanchez, V., \& Cortez-Lara, A. A. (2015). Minute 319 of the international boundary and water commission between the US and Mexico: Colorado River binational water management implications. International Journal of Water Resources Development, 31(1), 17-27.

Schulze, S. (2012). Public Participation in the governance of transboundary water resources: Mechanisms provided by river Basin organizations. L'europe En Formation, 365(3), 49-68.

Siegfried, T., \& Bernauer, T. (2007). Estimating the performance of international regulatory regimes: Methodology and empirical application to international water management in the Naryn/Syr Darya basin. Water Resources Research. https://doi.org/10.1029/2006WR005738

Schmeier, S., Gerlak, A. K., \& Blumstein, S. (2016). Clearing the muddy waters of shared watercourses governance: Conceptualizing international river basin organizations. International Environmental Agreements: Politics, Law and Economics, 16(4), 597-619.

Sneddon, C., \& Fox, C. (2006). Rethinking transboundary waters: A critical hydropolitics of the Mekong basin. Political Geography, 25(2), 181-202.

Suhardiman, D., Giordano, M., \& Molle, F. (2012). Scalar disconnect: The logic of transboundary water governance in the Mekong. Society \& Natural Resources, 25(6), 572-586.

Udall, B., \& Overpeck, J. (2017). The twenty-first century Colorado River hot drought and implications for the future. Water Resources Research, 53(3), 2404-2418.

UN-Water. (2020). Sustainable development goals indicator 6.5.2. transboundary water cooperation. Online Data Portal Available at: https://sdg6data.org/indicator/6.5.2.

United Nations Environment Programme (UNEP). (2016). Transboundary River Basins: Status and trends. Nairobi: UNEP.

United States Bureau of Reclamation (USBR). (2015). Moving forward, executive summary. US department of the interior bureau of reclamation. DC: US Bureau of Reclamation. At https://www.usbr.gov/ lc/region/programs/crbstudy/MovingForward/Phase1Report/fullreport.pdf.

United States Department of Interior (USDOI). (2000). Press release Mexican secretariat of environment, natural resources and fisheries (SEMARNAP) signed the joint declaration to enhance cooperation in the Delta.

United States Department of Interior (USDOI. (2001). Record of decision. Colorado River interim surplus guidelines. Final environmental impact statement.

United States Department of Interior (USDOI. (2007a). Record of decision. Colorado River interim guidelines for lower basin shortages and the coordinated operations for lake powell and lake mead. Final environmental impact statement.

United States Department of Interior (USDOI). (2007b). Press release Secretary Kempthorne announces joint US-Mexico statement on Colorado River issues.

United States Department of Interior (USDOI). (2009). Press release Secretary Kempthorne announces joint declaration on Colorado River issues.

United States Department of Interior (USDOI). (2019). Agreement concerning Colorado River drought contingency management and operations. Department of interior.

Wehn, U., Anema, K., Collins, K., Basco-Carrera, L., \& Lerebours, A. (2018). Stakeholder engagement in water governance as social learning: Lessons from practice. Water International, 43(1), 34-59.

Wilder, M. O., Varady, R. G., Gerlak, A. K., Mumme, S. P., Flessa, K. W., Zuñiga-Terán, A. A., \& Megdal, S. B. (2020). Hydrodiplomacy and adaptive governance at the US-Mexico border: 75 years of tradition and innovation in transboundary water management. Environmental Science \& Policy, 112, 189-202.

Young, O. R. (2017). Governing complex systems: Social capital for the anthropocene. MIT Press.

Zamora-Arroyo, F., Hinojosa-Huerta, O., Santiago, E., \& Brott, E. (2007). Collaboration in Mexico: Renewed hope for the Colorado River delta. Nevada Law Journal, 8, 871.

Zeitoun, M., \& Mirumachi, N. (2008). Transboundary water interaction I: Reconsidering conflict and cooperation. International Environmental Agreements: Politics, Law and Economics, 8(4), 297.

Zeitoun, M. (2013). Global environmental justice and international transboundary waters: An initial exploration. The Geographical Journal, 179(2), 141-149.

Zeitoun, M., Cascão, A. E., Warner, J., Mirumachi, N., Matthews, N., Menga, F., \& Farnum, R. (2017). Transboundary water interaction III: contest and compliance. International Environmental Agreements: Politics, Law and Economics, 17(2), 271-294. 
Publisher's Note Springer Nature remains neutral with regard to jurisdictional claims in published maps and institutional affiliations. 